\title{
PALEOZOIC INTRA-FORMATIONAL CONGLOMERATES *
}

\author{
BY CHARLES D. WALCOTT
}

(Presented before the Society December 28, 1893)

CONTENTS

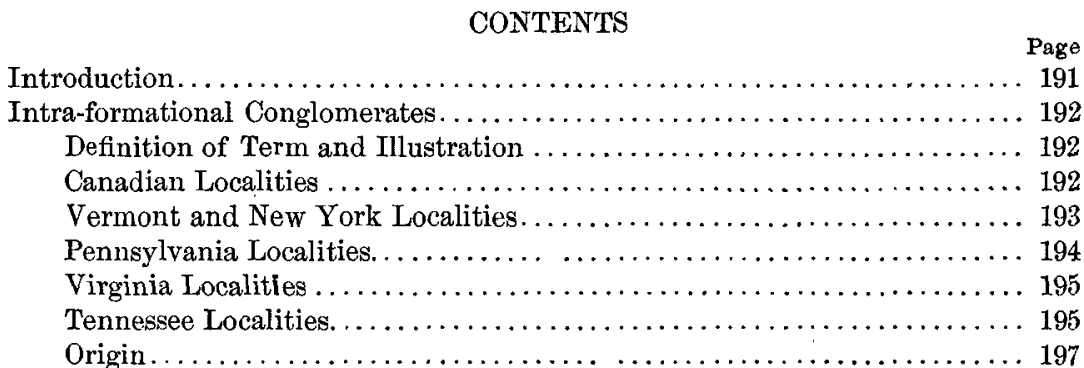

\section{INTRODUCTION.}

Usually the presence of a conglomerate in a stratigraphic series of rocks is a matter of considerable importance to the geologist. He naturally infers the presence of a break in the continuity of sedimentation; an orographic movement of greater or less extent; erosion of a prëexisting formation. He sees, in his mental review, the waves sorting and depositing sand, pebbles and bowlders derived from the uplifted land. The idea of the lapse of a period of time of considerable and often long duration is formed as he recalls orographic movement, erosion and unconformity of deposition. If the conglomerate is near the base of some formation or series of formations, he views it as almost conclusive evidence of the marked change that introduced the new deposits. This is all fair induction from observed facts, and it is the general and approved experience of geologists. When I ventured to describe to a veteran geologist the peculiarities of a formation of conglomerate that occurs in the Lower Cambrian rocks of the eastern United States he advised my reviewing my field work and opinions, as the latter were unusual. This

* Printed by permission of the Director of the U. S. Geological Survey. 
has been done and observations extended, with the result that I find the presence of intra-formational conglomerates a not uncommon phenomenon, one that must receive the attention of every field geologist working in the Appalachian region, from the Saint Lawrence valley in the northeast to the Cretaceous boundary of the Paleozoic of the far southwest in Georgia and Alabama.

Care is to be taken that intra-formational breccias are not confused with the intra-formational conglomerates. The former have a wide geographic distribution, and owe their origin to local disturbance within the beds affected, without presupposing elevation above sealevel and erosion.

\section{Intra-Formational Conglomerates.}

Definition of Term and Illustration.-An intra-formational conglomerate is one formed within a geologic formation of material derived from and deposited within that formation. An illustration occurs in the old limestone quarries on the east shore of the Hudson, below Schodack landing, Rensselaer county, New York. The section is formed of thinly bedded limestone, carrying the typical Olenelius fauna. Toward the summit of the quarry a band of conglomerate limestone rests conformably on the bedded limestone. Pebbles and fragments of several varieties of limestone occur, in which fragments of typical species of the Olenellus fauna were found. The conglomerate band varies in thickness from 2 to 6 feet, and it is capped by thinly bedded limestones that carry the same species of fossils as the limestones beneath the conglomerate and the bowlders in the conglomerate. It shows that the limestone pebbles, bowlders and brecciated fragments were formed from a calcareous sediment sufficiently consolidated to be broken up, more or less rounded by attrition and collected to form a bed of conglomerate, the matrix of which is usually calcareous. This section clearly proves the formation of conglomerate within the Lower Cambrian terrane, the materials of which were derived from limestones deposited during Lower Cambrian time.

The conglomerate at the locality described is not as clearly marked as some in the Lower Cambrian terrane of Lancaster and York counties, Pennsylvania, and in the conglomerates at the base of the great Ocoee series of Tennessee. The limestone conglomerates of the Cambrian and Ordovician of the Saint Lawrence valley are not typical illustrations of true intra-formational conglomerates, but I shall speak of them, as they appear to have been formed under somewhat similar conditions.

Canadian Localities. - Sir W. E. Logan has graphically described the limestone and conglomerates of the south shore of the Saint Lawrence at Trois Pistoles, Bic, Metis, the vicinity of Quebec and the west coast of 


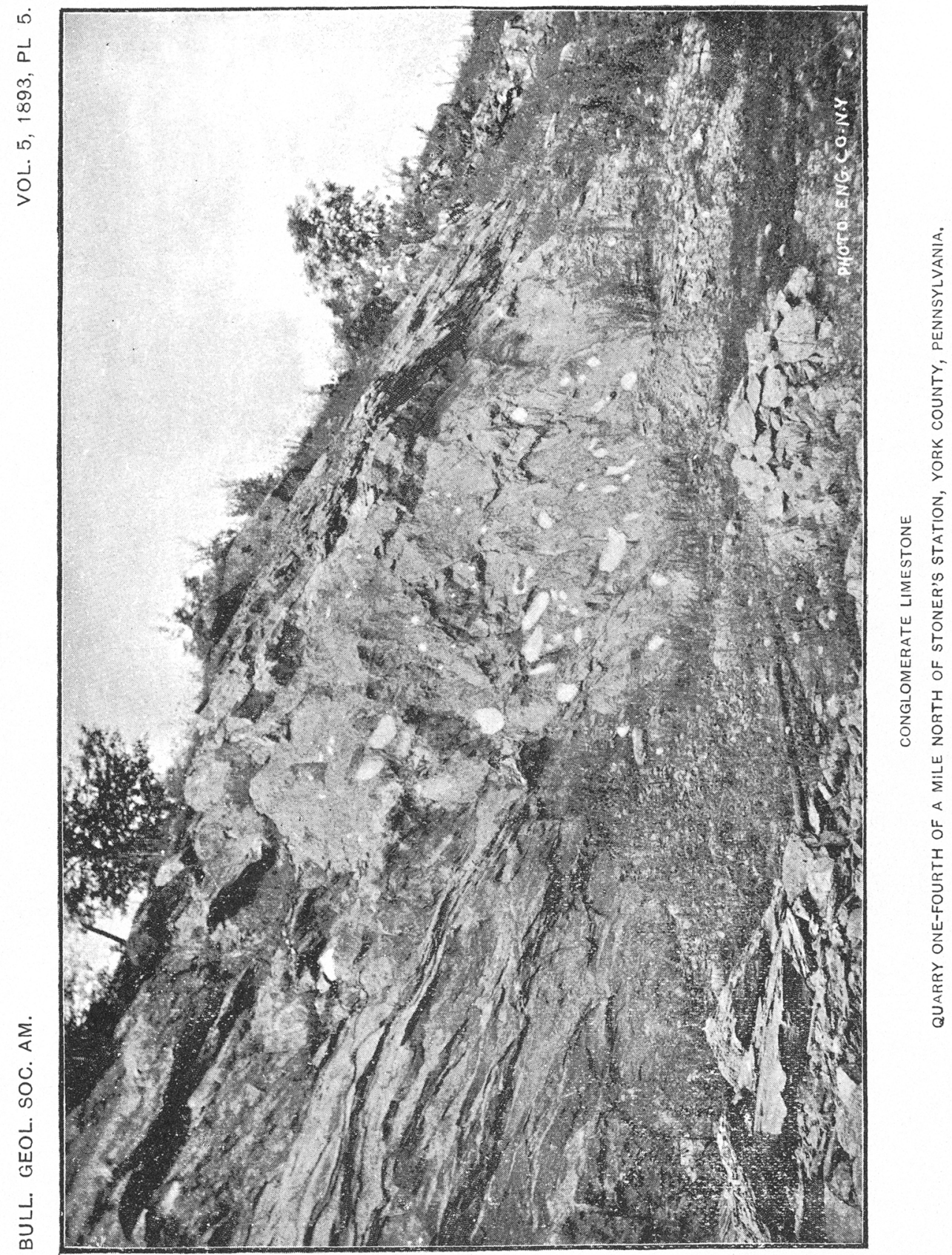


Newfoundland.* During the summer of 1889 I had an opportunity to examine the sections of the Ordovician and Cambrian rocks in the vicinity of Quebec, and I was very much impressed by the mode of occurrence of the limestone conglomerates. The lowest bed of conglomerate occurs in the Sillery shales, on the south shore of the Saint Lawrence below Levis, and on the south shore of the island of Orleans. The limestone bowlders show transportation, and are mingled with pebbles of quartz, sandstone, et cetera. The Olenellus fauna occurs abundantly in the fragments of limestone, but the source of the limestone is unknown. It is, however, of Cambrian age, and it has been redeposited about 1,500 feet from the summit of the series of shales, sandstones, et cetera, that are referred to the Cambrian. $\dagger$

The lower bed of limestone conglomerate at Point Levis occurs near the base of the Ordovician, in the Point Levis shale. It is made up of large and small bowlders of limestone, carrying the Upper Cambrian fauna, that are embedded in the limestone matrix in which occurs the typical Calciferous fauna. The matrix is a hard, gray, impure limestone which forms solid layers that were traced for over 500 feet on the strike. As in the case of the limestone bowlders carrying the Olenellus fauna, the origin of the bowlders carrying the Upper Cambrian fauna is unknown, as no beds of limestone of a similar character have been found in the Sillery shales upon which the Ordovician shales and interbedded conglomerate rest. The matrix of the conglomerate proves the formation to be of lower Ordovician age. In a bed of limestone fifty feet higher up in the section I found additional species of the Calciferous fauna, and in a bed of limestone conglomerate above this the fossils in the bowlders and in the matrix as well are of Calciferous age. In a search of two days I failed to find a Cambrian fossil at this horizon, although such an occurrence might be anticipated from the occurrence of the older limestones in the conglomerates beneath. This second band of conglomerate in the I.evis series appears to be a true intra-formational conglomerate. The limestone conglomerates embedded in the shales and shaly limestones beneath the city of Quebec are of much less stratigraphic importance than are those at Point Levis; but the same conditions of deposition appear to have existed during the formation of these rocks of middle Ordovician (Chazy-Trenton) time.

Vermont and New York Localities.-In the passage beds between the Cambrian and Ordovician east of Highgate springs, Franklin county, Vermont, layers of limestone conglomerate occur, some of the fragments of which carry the lower Ordovician fauna. The horizon of the con- 
glomerate appears to be within the range of this fauna, and points to an intra-formational origin.

The type that has already been described as occurring at Schodack landing, New York, has been observed at many localities to the north, in Washington county, New York, where it is a common feature of the Lower Cambrian terrane.

Pennsylvania Localities.-The succession of Cambrian rocks in York and Lancaster counties, Pennsylvania, is very clearly defined. A massive quartzite is succeded by shales, and then a massive bedded, more or less silicious limestone that varies in color and composition in its several beds. This massive bed of limestone is succeeded in numerous instances by beds of limestone conglomerate which are interbedded in more or less thinly bedded, somewhat shaly limestones. One of the most clearly defined sections is exposed at Bellemont, Lancaster county, on the line of the Pennsylvania railroad. The massive blue and white Cambrian limestones are succeeded by a few feet of a blue, earthy limestone and shale, and upon this there is a bed of limestone conglomerate, from eight to ten feet in thickness, that is made up largely of pebbles and bowlders of limestone derived from the limestone beds beneath. A second bed of conglomerate is seen on the roadside to the north.

About 40 miles west of Bellemont, at Stoners station, on the York and Wrightsville railroad, York county, Pennsylvania, an extensive exposure of the Lower Cambrian limestones and conglomerate is beautifully shown in an old quarry just east of the wagon-road, one-fourth of a mile north of the railroad track. Alternating bands of thinly bedded limestone and massive beds of limestone conglomerate form about 100 feet of the exposed section, in which five beds of the conglomerate limestone are well shown. The basal bed has a fine grained, gray limestone matrix with brecciated limestone fragments in it which range in size from that of small shot to masses three feet in diameter. These pebbles and bowlers vary in lithologic character, some resembling the matrix and others being oolitic, arenaceous, semi-marbleized and shaly limestones. The thinly bedded limestones separating the conglomerate bands are from four to six feet in thickness, and are very clearly defined.

In the second band of conglomerate the larger bowlders occur in the lower portion. The other three beds vary in details, but they are all formed of the same type of rock. One of the upper beds contains a multitude of small fragments of limestone. It was impracticable to obtain a photograph of the basal beds, which contain the largest bowlders. Plate 5 illustrates the evenly bedded limestones above and beneath the third band, and also shows the character of some of the limestone bowlders. In the shaly limestone at the base of this bed a large bowlder, 
. 


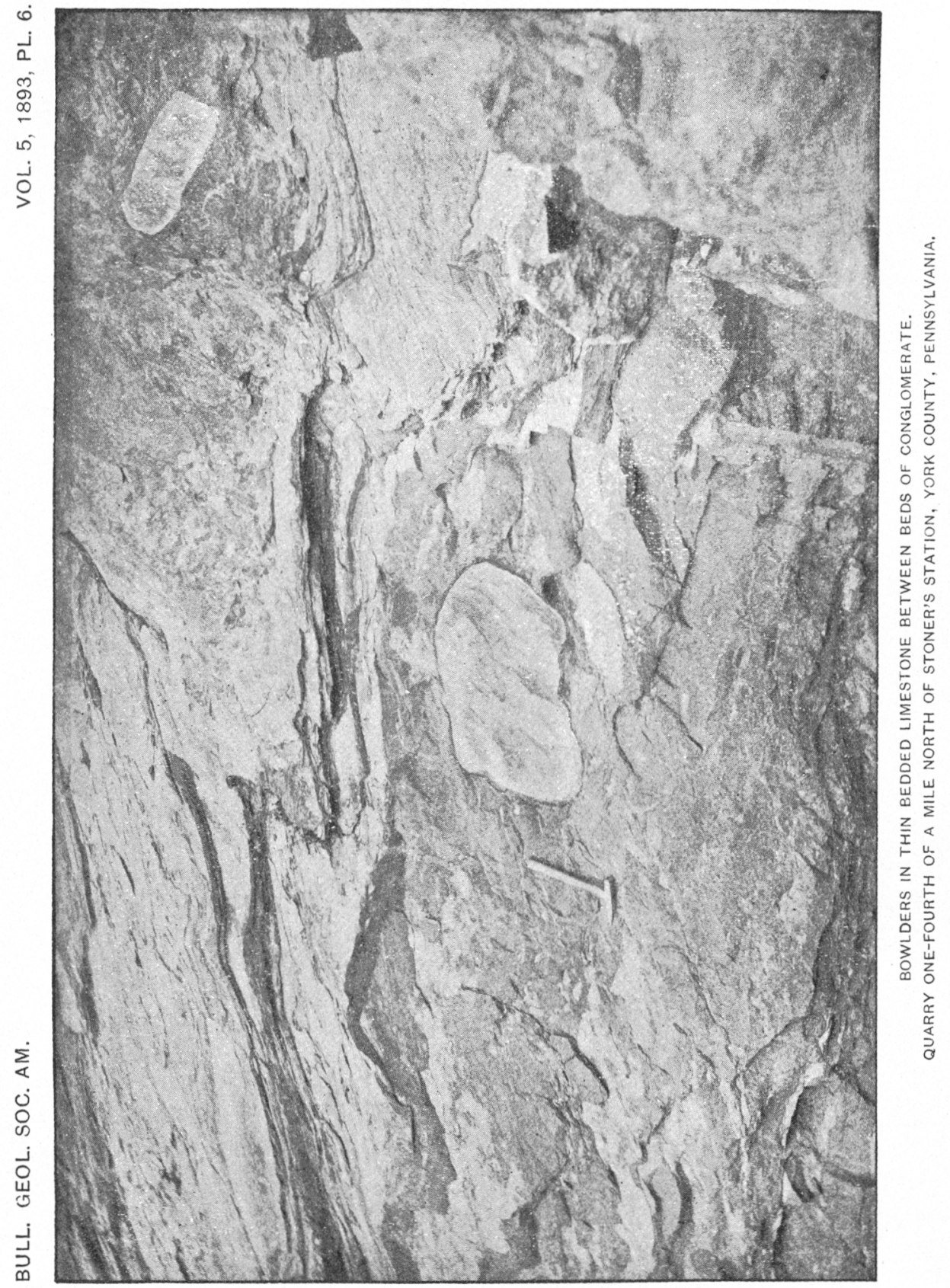


two feet or more in diameter, is entirely embedded in the shaly limestone. This bowlder, as shown in plate 6, was evidently deposited on the bed of the sea and the calcareous mud gathered quietly about it. At about the same horizon, in a quarry on the east side of York, a massive bed of limestone conglomerate is beautifully shown. A photograph of it is reproduced as plate 7 .

The quartzites, shales and limestones beneath these beds of conglomerate are known to carry the Lower Cambrian or Olenellus fauna; and the same fauna, with the exception of details of variation of species, occurs in the limestones and shales above the conglomerates, thus placing the latter within the definition of intra-formational conglomerates.

Virginia Localities.-Mr M. R. Campbell* informs me that in the vicinity of Radford, Virginia, there is a formation that appears to be a true intraformational conglomerate. He states that it is in the great CambroSilurian limestone, and consists of a yellowish white, chalky limestone matrix, in which are embedded rounded fragments of limestone that are similar in composition to the matrix, and that can only be distinguished from it with difficulty. A few small grains of foreign material were observed. The exact stratigraphic horizon could not be determined, owing to the complexity of the structure and the poor exposures. Two miles below Radford the actual contact was observed between the conglomerate and the bedded limestone, where the former rests on the cut edges of the folded limestones beneath. Mr Campbell believes this indicates shore conditions, contortion of the limestone deposits and their elevation above sealevel, to form cliffs that supplied material for later beds of the same great formation.

Another case of this kind was observed by Mr Campbell at a horizon north west of Bristol, Virginia. He found that here the conglomerate occurs in a bed of shaly limestone, but a few feet thick, that belongs in the Nolichucky (Cambrian) shales. This bed appears to have been broken up largely into flat fragments that were quite well worn on their edges, and then redeposited in the same bed and cemented into a solid mass of limestone. The peculiar feature of this deposit is its extreme thinness and the apparent freedom from all marks of erosion. It is quite persistent and no evidence of an unconformity was observed.

Tennessee Localities. - The intra-formational conglomerates already described have been identified as such by the presence of similar fossils in the bowlders of the conglomerate and the superjacent and subjacent bedded limestones. Those about to be described are identified entirely by lithologic characters. These, however, are so clearly defined and are

* Paleozoic Overlaps in Montgomery and Pulaski Counties, Virginia: Bull. Geol. Soc. of Am, vol, 5, pp. 175-176. 
of such variety that the conclusions based upon them are considered to be nearly as reliable as those where fossils are present.

In Tennessee these conglomerates occur in the lower portion of the Ocoee terrane of Safford. Mr Arthur Keith named the basal slate the Wilhite. This slate rarely exceeds 700 feet in thickness, and it is capped by the silicious Citico conglomerate (Keith). Within the Wilhite slate, especially in the upper 200 feet, and along its strike for over 100 miles, numerous beds of limestone occur. Usually a limestone conglomerate is found in the same section, generally above the bedded limestone. These limestone conglomerates have been cited as proof that the Wilhite slates were of later age than the Ordovician limestones, which were assumed as having furnished the pebbles and bowlders of the limestone conglomerates and hence that the Ocoee terrane instead of being an older formation than the great limestone series of Tennessee was of later date, and hence of post-Ordovician age.

In company with Mr Keith I visited numerous localities of the Wilhite slate in Cocke, Sevier and Blount counties. At a locality three miles south, $65^{\circ}$ east of East Fork, Sevier county, a limestone conglomerate occurs by the roadside and also on the north side of the road on Stephen Huff's farm. The bedded limestones vary in texture and color and in the presence or absence of more or less arenaceous material, but. the weathered surfaces of many of the beds are very characteristic. At the locality by the roadside there is little, if any, of the bedded limestone exposed, the conglomerate resting on the calcareous shale or slate containing compressed lentiles of impure bituminous limestone. The conglomerate is formed of brecciated and rounded pebbles and bowlders of limestone and, more rarely, of a fine grained sandstone. The limestone bowlders vary in lithologic characters from pure white limestone to sandy and silicious and their various combinations. In colori they are blue, gray, black, purple, white, pinkish, dove, etcetera. About two miles to the north of this locality, on Wilhite creek, there occurs a somewhat similar conglomerate, in which the limestone bowlders reach a diameter of from three to four feet. A peculiarity of the conglomerate at these places is the presence of large bowlders in the slate above the main body of the conglomerate.

At a locality two miles east of Jones cove, Sevier county, an interesting phase of the conglomerate is the presence of bowlders of a dark, sandy limestone embedded in the mass of the bedded limestone that occurs below and also above the conglomerate. The matrix of the conglomerate is frequently largely made up of a sandy limestone of the same lithologic aspect as the bedded limestones out of which were made the bowlders of the conglomerate. The limestone conglomerate was also 


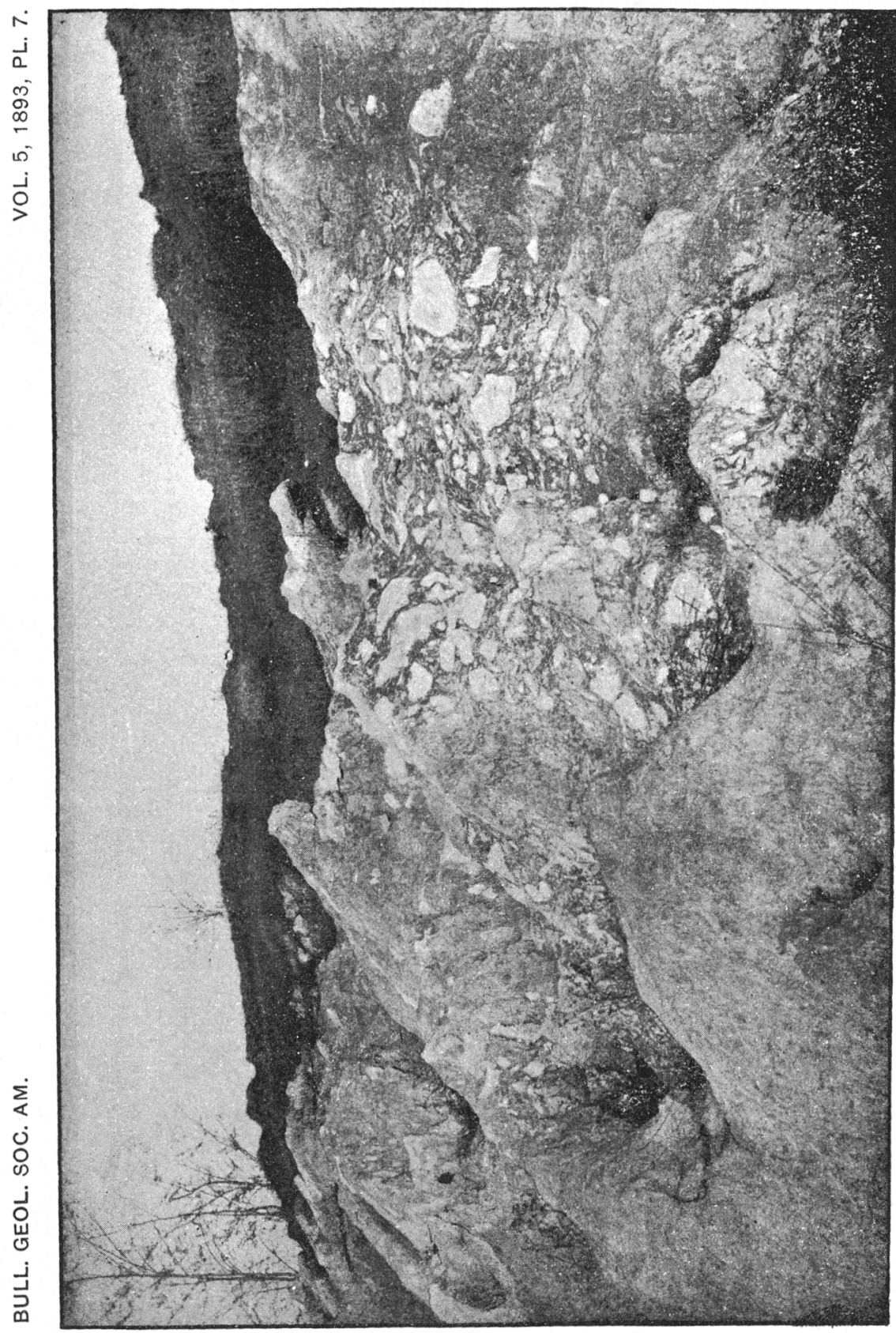

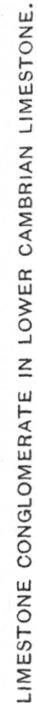




\section{.}


noted at a locality three miles south of Del Rio, Cocke county, where it occurs above the limestone in the Wilhite slate.

One of the best localities to study the relations of the limestones and conglomerates is on the north side of the entrace to the narrows of the Little Tennessee river, in Blount county. Here the bedded limestones in the Wilhite slates are beautifully exhibited, and above them the limestone conglomerate is strongly marked, and bowlders of the limestone over six feet in diameter occur in the lower portion of the Citico conglomerate. Another peculiarity at this locality is that the limestones within the Wilhite slate were broken up and many of the fragments rounded to form a bed of conglomerate just above the horizon of the limestone beds from which, elsewhere, they were derived, and that the same process was repeated with the bed of conglomerate. We found, in an upper bed of conglomerate, bowlders formed of masses of conglomerate of the same character as in the stratum some distance below in the section. In this upper conglomerate numerous quartz pebbles of the same character as those of the Citico conglomerate are embedded in the limestone matrix. Special effort was made by both Mr Keith and myself to discover evidences of the presence of limestones of a different character from those found conformably bedded in the Wilhite slate, but without șuccess. The limestones of the Wilhite slate are so marked in their lithologic characters and the bowlders in the conglomerates have lithologic characters so similar that we did not hesitate to refer the source of the material of the latter conglomerate to the limestone beds within the Wilhite formation. At one locality, two miles south $10^{\circ}$ west of Sweetwater, Cocke county, a sandstone rests unconformably upon the Knox limestone and contains rounded pebbles of the limestone carrying the characteristic fossils which are embedded in the limestone beneath the sandstone. This sandstone occurs in the isolated outcrop, and is not known to be of Ocoee age.

Origin.-The relation of the bedded limestones to the superjacent conglomerates proves that the calcareous mud which was subsequently consolidated into the limestones solidified soon after deposition. This is shown by the presence in the conglomerate of rounded pebbles and angular fragments of limestone with sharp clear cut edges. The presence of the conglomerates above the limestone beds, from some portion of which they were derived, leads me to believe that the sea-bed was raised in ridges or domes above the sealevel and thus subjected to the action of the seashore ice, if present, and the aërial agents of erosion. From the fact that the limestones upon which the conglomerates rest rarely if ever show traces of erosion where the conglomerates come into contact with them, the inference is that the débris worn from the ridges was 
deposited in the intervening depressions beneath the sea. In the case of the conglomerates of the.Wilhite slates of Tennessee it is exceptional to find a bedded limestone above them; but within the Lower Cambrian of Pennsylvania and New York the conglomerates are interbedded in the limestones.

Large bowlders of limestone were observed in the Wilhite slates on Wilhite creek; Tennessee, above the main conglomerate bed, and large bowlders of limestone were observed in the bedded limestones at Stoner's quarry, Pennsylvania. The mode of occurrence of these bowlders, especially those in the limestones at Stoner's quarry, leads to the view that they may have been dropped upon the sea-bed from floating ice. No other explanation occurs to me that will account for the transportation of a bowlder from the shoreline and the placing of it upon the seabed so as not to disturb to any marked degree the sediment then accumulating. In the special example at Stoner's quarry two feet of calcareous mud was deposited in thin layers about the bowlder and as much more above it before the introduction of conditions that deposited the next stratum of conglomerate.*

The history of Appalachian sedimentation and mountain-building proves that a more or less constant movement was taking place from Algonkian time to the close of the Paleozoic. This movement was at times greatly prolonged and resulted in marked topographic features. More frequently the minor movements produced local effects, and some of them resulted in the formation of the conglomerates described.

* Sir William Dawson says that the "only means of explaining these conglomerates [Quebec, Point Levis, Metis] seems to be the action of cotst ice, which at this period appears to have been as energetic on the American shores as at the present day, and seems to have had great reefs of limestone, probably in the area of the gulf of Saint Lawrence, to act upon and to remove in large slabs and bowlders, piling these up on banks to constitute masses of conglomerate." Quart. Jour. Geol. Soc., London, November, 1888, pp. 809, 810. 